\title{
DAMPAK PEMASARAN RAMAH LINGKUNGAN TERHADAP MANAJEMEN RANTAI PASOKAN DI PASAR INDUSTRI
}

\author{
Mona Karina \\ University of M H Thamrin \\ Email: Karina_karinaziid@yahoo.com
}

\begin{abstract}
Abstrak
Pemasaran dan rantai pasokan ramah lingkungan telah menarik perhatian akademisi dan praktisi dalam dekade terakhir. Namun, belum ada kerangka kerja holistik yang dikembangkan tentang cara membangun merek industri dan perusahaan yang ramah lingkungan. Apakah rantai pasokan ramah lingkungan/berkelanjutan dapat diintegrasikan dengan pemasaran industri ramah lingkungan dalam membangun organisasi yang lebih ramah lingkungan dan merek industri masih belum jelas. Selain itu, sedikit yang diketahui tentang faktor-faktor pada pengembangan produk industri ramah lingkungan baru atau bagaimana produk industri ramah lingkungan baru diadopsi oleh organisasi atau perusahaan. Selain itu, kita hanya tahu sedikit tentang apakah dan bagaimana rantai pasokan ramah lingkungan memungkinkan pengembangan produk industri ramah lingkungan baru. Masalah khusus ini bertujuan mencerminkan kemajuan terbaru pada pemasaran industri ramah lingkungan, rantai pasokan ramah lingkungan/berkelanjutan dan interaksi mereka dalam merek industry ramah lingkungan, dan untuk mengeksplorasi arah penelitian masa depan.
\end{abstract}

Kata Kunci: Pemasaran Ramah Lingkungan, Rantai Pasokan Ramah Lingkungan, Industri Pemasaran.

\begin{abstract}
Green marketing and supply chains have attracted the attention of academics and practitioners in the past decade. However, no holistic framework has yet been developed on how to build environmentally friendly industrial and corporate brands. Whether an environmentally friendly/sustainable supply chain can be integrated with marketing an environmentally friendly industry in building a more environmentally friendly organization and industrial brand remains unclear. In addition, little is known about factors in developing new environmentally friendly industrial products or how new environmentally friendly industrial products are adopted by organizations or companies. In addition, we know very little about whether and how environmentally friendly supply chains enable the development of new environmentally friendly industrial products. This particular issue aims to reflect the latest advancements in marketing green industries, sustainable/green supply chains and their interactions in green industry brands, and to explore future research directions.
\end{abstract}

Keywords: Green Marketing, Green Supply Chain, Marketing Industry. 


\section{A. PENDAHULUAN}

Merek Ramah lingkungan dan keberlanjutan telah menarik banyak perhatian baik para praktisi dan akademisi dari berbagai disiplin bisnis, seperti pemasaran, manajemen rantai pasokan, dan manajemen informasi. Terlepas dari meningkatnya arti untuk menjadi lebih ramah lingkungan dan lebih berkelanjutan (karena, misalnya, perubahan iklim dan undangundang lingkungan), tidak ada kerangka kerja holistik tentang bagaimana membangun merek industri ramah lingkungan dan merek perusahaan. Membangun merek industri ramah lingkungan yang kuat tidak hanya membutuhkan pemasaran ramah lingkungan, tetapi juga operasi ramah lingkungan dan manajemen rantai pasokan ramah lingkungan. Selain itu, globalisasi dan sumber internasional memberikan tekanan dan tantangan ekstra untuk merancang dan mengimplementasikan rantai pasokan yang benar-benar ramah lingkungan dan berkelanjutan dari perspektif global.

Apakah rantai pasokan ramah lingkungan berkelanjutan dapat diintegrasikan dengan pemasaran industri ramah lingkungan dalam membangun organisasi dan merek industri yang lebih ramah lingkungan masih belum jelas. Misalnya, bagaimana industri atau organisasi dapat menggunakan keberlanjutan rantai pasokan dan pemasaran industri ramah lingkungan untuk menciptakan keunggulan kompetitif di pasar dan di sepanjang jaringan rantai pasokan tidak dirumuskan dengan baik. Dari operasional dan sisi rantai pasokan, misalnya, pengurangan limbah (seperti efisiensi operasional, pengiriman dan jaringan distribusi), yang merupakan inti dari perampingan operasional, bisa dianggap sebagai bentuk keberlanjutan.

Kemajuan teknologi informasi juga dapat membantu mengurangi pemborosan (mis. Kertas dan energi) ke tingkat tertentu. Sejumlah alat lain seperti penilaian siklus hidup, desain ramah lingkungan untuk pengembangan produk dll tersedia. Namun, mereka, termasuk filosofi perampingan, tetapi tidak terkait dengan pemasaran industri. Ini tidak mengherankan karena alat atau teknik yang disebutkan sebelumnya lebih terlihat secara internal daripada eksternal. Dari perspektif pemasaran, misalnya, meskipun konsumen dan konsumsi ramah lingkungan telah mendapat perhatian, sedikit yang diketahui tentang faktorfaktor pada pemasaran $\mathrm{B} 2 \mathrm{~B}$ (Bisnis ke Bisnis) ramah lingkungan dan perilaku pembelian organisasi ramah lingkungan.

Pemahaman yang lebih baik tentang bagaimana dan mengapa organisasi memilih supplier yang ramah lingkungan memiliki implikasi yang signifikan untuk pemasaran B2B ramah lingkungan. Merek industri ramah lingkungan bisa menjadi upaya penting dalam pemasaran industri keberlanjutan. Namun, pengembangan lebih lanjut dalam hal ini 
diperlukan. Selain itu, branding industri ramah lingkungan membutuhkan pengembangan produk industri ramah lingkungan. Sedikit yang diketahui tentang faktor-faktor pada pengembangan produk industri baru ramah lingkungan atau bagaimana produk industri baru ramah lingkungan diadopsi oleh organisasi. Secara spesifik, kita tahu sedikit tentang apakah dan rantai pasokan ramah lingkungan memungkinkan pengembangan produk industri baru ramah lingkungan.

Dalam editorial ini, kami pertama meninjau beberapa literatur kunci yang berkaitan dengan strategi ramah lingkungan pemasaran, manajemen rantai pasokan ramah lingkungan, dan peran teknologi dalam manajemen ramah lingkungan. Kami kemudian memperkenalkan artikel yang muncul.

\section{B. LANDASAN TEORI}

\section{Strategi Pemasaran Ramah Lingkungan}

Pemasaran dan ramah lingkungan merupakan isu strategis (Siegel, 2009), bukan hanya karena menjadi ramah lingkungan membuat perusahaan terlihat bagus, tetapi juga karena menjadi punya daya saing kuat (Ambec \& Lanoie, 2008; Russo \& Fouts, 1997). Selain itu, tekanan kelembagaan dan pemangku kepentingan mendorong untuk mengadopsi strategi pemasaran ramah lingkungan (Cronin, Smith, Gleim, Ramirez, \& Martinez, 2011; Sarkis, Gonzalez-Torre, \& Adenso-Diaz, 2010). Mengintegrasikan isu-isu lingkungan ke dalam proses pemasaran strategis telah menjadi penting, hal ini bertujuan bagi perusahaan untuk mencapai legitimasi kelembagaan dan keunggulan kompetitif (Handelman \& Arnold, 1999). Strategi pemasaran ramah lingkungan telah menarik perhatian akademis selama dua dekade terakhir. Menon dan Menon (1997:54) mengusulkan bahwa strategi pemasaran ramah lingkungan yang efektif harus didukung oleh prinsip-prinsip pemasaran kewirausahaan berwawasan lingkungan, yang mengacu pada "proses untuk merumuskan dan melaksanakan kewirausahaan dan manfaat lingkungan dengan tujuan menciptakan pendapatan dengan menyediakan pertukaran yang memuaskan untuk memenuhi tujuan kinerja ekonomi dan sosial perusahaan.

Banerjee, Iyer, dan Kashyap (2003) memperluas konsep awal Menon dan Menon (1997) untuk memasukkan orientasi lingkungan dan strategi lingkungan, dan mengembangkan konsep lingkungan perusahaan. Lingkungan perusahaan mencakup dua elemen inti: orientasi lingkungan dan strategi lingkungan. Orientasi lingkungan mengacu pada pengakuan manajer senior tentang pentingnya masalah lingkungan yang dihadapi 
perusahaan mereka; sementara strategi lingkungan mengacu pada sejauh mana isu-isu lingkungan yang terintegrasi dengan rencana strategis perusahaan (Banerjee et al., 2003). Menurut Banerjee et al. (2003), orientasi lingkungan berdampak positif pada strategi lingkungan, yang pada gilirannya memiliki dampak positif pada kinerja di bawah beberapa kondisi (Menguc \& Ozanne, 2005). Baru-baru ini, Chan (2010) menemukan bahwa dampak orientasi lingkungan strategi lingkungan secara positif dimoderatori oleh pengaruhregulasi pemangku kepentingan.

Awalnya Menon dan Menon (1997) menawarkan kerangka kerja konseptual pada anteseden dan hasil dari pasar kewirausahaan berwawasan lingkungan. Mereka menyarankan bahwa pemasaran kewirausahaan berwawasan lingkungan dapat berdampak pada kinerja bisnis dan reputasi perusahaan, dan efek tersebut cenderung lebih kuat jika industri perusahaan memiliki reputasi yang lebih baik. Mereka lebih lanjut berpendapat bahwa pemasaran kewirausahaan berwawasan lingkungan ini akan didorong lebih tinggi oleh kebijakan internal perusahaan (misalnya, manajemen sensibilitas lingkungan) dan kebijakan eksternal (pelanggan kepekaan lingkungan, intensitas regulasi), struktur internal (misalnya sentralisasi pengambilan keputusan) dan ekonomi eksternal (mis. intensitas persaingan). Namun, ini adalah proposisi konseptual tanpa dukungan dari bukti empiris. Baker dan Sinkula (2005) mengembangkan suatu ukuran untuk pemasaran kewirausahaan berwawasan lingkungan dan secara empiris menemukan bahwa pemasaran kewirausahaan berwawasan lingkungan memiliki dampak positif pada kemampuan perusahaan, seperti keberhasilan pengembangan produk baru. Banerjee et al. (2003) mengidentifikasi dan secara empiris menguji satu set anteseden yang sama dari perusahaan berwawasan lingkungan. Antesedenanteseden ini termasuk komitmen manajemen teratas, kepedulian publik, kekuatan regulator dan sebagainya. Mereka juga menemukan bahwa sektor industri (sektor dampak lingkungan tinggi vs. sedang) memoderasi dampak dari beberapa anteseden lingkungan perusahaan. Baik Menon dan Menon (1997) dan Banerjee et al. (2003) menekankan peran penting tim manajemen puncak, yang menunjukkan pentingnya kepemimpinan dalam mengadopsi strategi pemasaran ramah lingkungan. Memang, Egri dan Herman (2000) menemukan nilainilai personal pemimpin (misalnya, lebih eko sentris, keterbukaan terhadap perubahan, dan melampaui diri) dan gaya kepemimpinan transformasi memiliki dampak positif pada strategi lingkungan perusahaan. 


\section{Manajemen Rantai Pasokan Ramah Lingkungan}

Sebuah rantai pasokan dapat didefinisikan sebagai jaringan perusahaan yang bekerja sama menuju tujuan (misalnya layanan pelanggan, pemenuhan dan sebagainya) dari seluruh rantai pasokan (Chan \& Chan, 2010). Manajemen rantai pasokan dengan demikian sangat digabungkan dengan alokasi sumber daya dan karenanya berbagai teknik optimasi dapat ditemukan dalam literatur untuk membantu proses pengambilan keputusan (Chan, 2011). Karena itu, antarmuka pemasaran dan manajemen rantai pasokan tidak dapat diabaikan (Lambert \& Cooper, 2000). Sebagai contoh, Jüttner, Christopher dan Baker (2007) meneliti bagaimana mengintegrasikan kegiatan pemasaran dan rantai pasokan dari sudut pandang rantai permintaan. Tujuan dari makalah ini adalah untuk mengusulkan model bisnis baru yang dapat menambah nilai di sepanjang rantai. Dengan cara yang sama, manajemen rantai pasokan ramah lingkungan (misalnya Lamming \& Hampson, 1996) dan pemasaran ramah lingkungan (misalnya Cronin et al., 2011) tidak dapat dianggap secara terpisah. Namun demikian, antarmuka antara penelitian rantai pasokan ramah lingkungan dan pemasaran ramah lingkungan agak tidak jelas. Hal ini terutama jika upaya yang ditujukan untuk hasil manajemen rantai pasokan ramah lingkungan di keuntungan marginal saja (misalnya Côté, Lopez, Marche, Perron dan Wright, 2008).

\section{Kinerja Perusahaan}

Kebanyakan penelitian manajemen rantai pasokan ramah lingkungan digabungkan dengan kinerja perusahaan dan karenanya berusaha untuk menyimpulkan bahwa rantai pasokan ramah lingkungan dapat mempengaruhi keuntungan perusahaan atau bahkan keuntungan daya saing (misalnya Zhu \& Sarkis, 2004). Bowen, Cousins, Lamming, dan Faruk (2001) berpendapat bahwa insentif finasial adalah kekuatan pendorong utama untuk menerapkan rantai pasokan ramah lingkungan. Rao dan Holt (2005) meneliti hubungan antara praktek manajemen rantai pasokan ramah lingkungan dan daya saing perusahaan serta kinerja ekonomi, dan mereka menyatakan bahwa ada hubungan positif. Chiou, Chan, Lettice, dan Chung (2011) juga mencapai kesimpulan yang sama meskipun studi mereka hanya berfokus pada pasar Taiwan. Vachon dan Klassen (2008) menyimpulkan ada korelasi antara kinerja lingkungan dan keunggulan kompetitif dalam survei mereka. Terlepas dari besarnya jumlah studi dalam literatur sehubungan dengan di atas, hubungan antara kegiatan manajemen rantai pasokan ramah lingkungan, misalnya manajemen pemasok ramah lingkungan (misalnya Bai \& Sarkis, 2010), pembelian ramah lingkungan (mis. Green, Morton, \& New, 1998) dan 
kegiatan pemasaran ramah lingkungan, misalnya merek ramah lingkungan, tampaknya hilang.

\section{Pengembangan Produk}

Pengembangan produk ramah lingkungan juga ditemukan dibarengi dengan kinerja perusahaan (misalnya Lau, Tang, \& Yam, 2010). Khususnya, Chen, Lai, dan Wen (2006) menemukan bahwa produk ramah lingkungan dan inovasi proses manufaktur ramah lingkungan secara positif terkait dengan keunggulan kompetitif perusahaan. Namun, beberapa hasil penelitian dari studi, konservatif pada aspek ini (misalnya Ragatz, Tangan fi eld, \& Petersen, 2002). Memperluas diskusi seputar mengintegrasikan manajemen rantai pasokan ramah lingkungan dan pemasaran ramah lingkungan, adalah penting untuk memahami interaksi dan kemungkinan tumpang tindih antara dua praktik. Namun, pengembangan produk ramah lingkungan bukanlah analisis langsung dan karenanya beberapa alat ilmiah diusulkan untuk mengukur upaya tersebut dari perspektif sadar lingkungan. Sebagai contoh, Yung et al. (2011) mengusulkan pendekatan siklus hidup untuk menganalisis opsi pengembangan produk ramah lingkungan dari produk elektronik. Namun, pendekatan semacam itu mungkin terlalu membosankan dalam hal pengumpulan data, dan sulit untuk dikaitkan dengan upaya pemasaran ramah lingkungan karena analisisnya tidak mudah disajikan kepada pelanggan. Selain itu, metode ini terutama digunakan pada tingkat produk, bukan tingkat rantai pasokan (Schmidt \& Schwegler, 2008). Dengan kata lain, upaya seperti itu tidak mudah terlihat oleh konsumen.

\section{Perampingan}

Perampingan, kadang-kadang disebut sebagai ketepatan, bertujuan untuk mengoptimalkan proses dengan menghilangkan limbah yang muncul dalam arti yang lebih luas (Bruce, Daly, \& Towers, 2004; Chan, Yin, \& Chan, 2010; Hines, Holweg, \& Rich, 2004). Konsep ini telah diterapkan di beberapa sektor selain sistem manufaktur tradisional, seperti sektor kesehatan (Mustaffa \& Potter, 2009). Asumsi utama atau prasyarat dari sistem perampingan yang merupakan kemampuan untuk memastikan sumber daya yang dikonsumsi adalah cara yang halus dan interupsi. Dengan kata lain, tingkat ketidakpastian yang tinggi akan menghambat penerapan filosofi perampingan untuk tidak hanya pda rantai pasokan ramah lingkungan atau kegiatan pemasaran ramah lingkungan, tetapi juga pada antarmuka mereka. 


\section{Distribusi dan Logistic Terbalik}

Jaringan distribusi memainkan peran penting antara pemasaran dan antarmuka rantai pasokan. Jelas, ini adalah keprihatinan utama dari manajemen rantai pasokan dari perspektif biaya dan arus bahan. Selain itu, ini juga merupakan titik di mana perusahaan dapat bertemu pelanggan, terutama untuk bisnis industri. Seperti penilaian siklus hidup yang disebutkan di atas, jejak karbon adalah parameter lain untuk menggambarkan "keramah lingkunganan" suatu produk atau proses. Misalnya, Edwards, McKinnon, dan Cullinane (2010) dibuat menggunakan indikator tersebut untuk menghitung yang disebut "jarak terakhir" jaringan distribusi dan berusaha untuk membandingkan skenario yang berbeda. Meskipun pendekatan ini secara ilmiah objektif, kekurangan yang sama untuk penilaian siklus hidup berlaku.

Berbeda dengan pengiriman produk dari gudang, misalnya, ke pelanggan, logistik terbalik melibatkan gerakan ke arah yang berlawanan (Chan, 2007). Pengunaan kembali, produksi ulang, dan daur ulang dari produk yang dikembalikan jelas berguna untuk mengurangi dampak lingkungan dari rantai pasokan. Sayangnya, aktivitas-aktivitas tersebut, termasuk desain produk ramah lingkungan yang disebutkan di atas, biasanya didorong oleh regulasi (Maxwell \& Van der Vorst, 2003). Namun, nilai produk yang dikembalikan tidak sperti yang diperkirakan (Blackburn, Guide, Souza, \& Van Wassenhove, 2004). Oleh karena itu, peran logistik terbalik dalam pemasaran industri tidak dapat diabaikan. Ini sangat penting ketika kemasan industri terlibat. Wadah yang dapat dikembalikan hanyalah salah satu contoh (Kroon \& Vrijens, 1995).

\section{HASIL DAN PEMBAHASAN}

\section{Peran Teknologi dan Inovasi yang Memungkinkan untuk Rantai Pasokan Ramah Lingkungan}

Sejak dua dekade lalu, konsep "Ramah lingkungan" terutama di wajibkan oleh pemerintah. Misalnya, Komisi Perdagangan Federal Amerika Serikat (FTC, 2012) memulai proses audit pada awal 1990-an untuk merek komersial di Green Marketing (pemasaran ramah lingkungan). Sekitar periode yang sama, Komisi Praktik Perdagangan Australia (digantikan oleh Komisi Persaingan dan Konsumen Australia sejak 1995, ACCC, 2011) juga mendaftarkan serangkaian kriteria untuk memantau pemasaran komersial, dua di antaranya secara khusus terkait dengan rantai pasokan ramah lingkungan. Mereka adalah: 1) ketika mempromosikan produk baru dengan membandingkan merek yang lain, fitur yang terkait dengan konsep ramah lingkungan perlu didefinisikan dengan jelas dan disajikan kepada 
pelanggan; 2) deskripsi detail dari kondisi yang dapat menghasilkan manfaat ke lingkungan. Standar industri juga telah mengikuti seruan inisiatif pemerintah seperti seri ISO 14000 yang dikembangkan oleh Organisasi Internasional untuk Standardisasi (2004) untuk membangun sistem manajemen yang berorientasi lingkungan. Saat ini, mematuhi standar membawa perusahaan tidak hanya sebagai image ramah lingkungan tetapi juga sering merupakan permintaan dari pelanggan bisnis utama (misalnya, Toyota dan GM meminta pemasok mereka untuk memenuhi standar seperti itu). Standar dan kondisi yang disebutkan di atas sebenarnya termasuk proses dan produk dalam berbagai kegiatan rantai pasokan.

Sebagaimana dibahas dalam bagian sebelumnya, menciptakan rantai pasokan sesuai dengan inisiatif ramah lingkungan melibatkan dengan proses untuk mengkonversi input ke output yang dapat bermanfaat ke lingkungan. Berkaca pada sifat kompleks dari manajemen rantai pasokan, literatur juga membahas rantai pasokan ramah lingkungan dari berbagai aspek. Faktanya, prosesnya mungkin termasuk sumber bahan ramah lingkungan (misalnya, Green et al., 1996), desain manufaktur ramah lingkungan (mis. lebih sedikit energi atau lebih sedikit polusi), perakitan, penyimpanan dan distribusi, dan penjualan, dan output akan menghasilkan limbah minimum melalui logistik terbalik untuk klaim ulang produk, penggunaan kembali atau pembuangan limbah (mis. Messelbeck \& Whaley, 1999 - studi industri kesehatan; Narasimhan dan Carter, 1998).

Selain standar industri dan peraturan pemerintah, ada dua faktor pendukung utama untuk memfasilitasi adopsi rantai pasokan ramah lingkungan. Sebagai salah satu faktor pendukung utama, kerangka kerja pengukuran kinerja dikembangkan (misalnya, Godfrey, 1998; Hervani et al., 2005). Tidak hanya sebagai alat untuk desain dan evaluasi kinerja rantai pasokan ramah lingkungan, kerangka kerja ini juga dapat bertujuan untuk memastikan manfaat terkait seperti pengurangan bahan dijual, pengembangan produk sampingan dari limbah, dan pelacakan sistemik pada zat berbahaya yang dihasilkan, dan konsumsi energi lebih sedikit. Pendukung lainnya, inovasi dan penggunaan teknologi tampaknya sedang dalam penelitian dari aspek manajerial. Bahkan, menerapkan kontrol kinerja bergantung pada sistem informasi untuk mengumpulkan angka operasional. Tidak seperti pengukuran kinerja, hanya ada sangat sedikit studi yang dilaporkan dalam jurnal aliran utama dari aspek sistem informasi dalam 10 tahun terakhir dan semuanya bersifat konseptual (Melville, 2010). Meskipun demikian, inovasi dan teknologi jelas dipandang dalam industri sebagai pendorong utama rantai pasokan ramah lingkungan. Misalnya, Epson banyak berinvestasi pada inovasi produk ramah lingkungan. dia mengadopsi teknik pelapisan tanpa permukaan untuk sebagian 
besar printernya yang telah menghemat 28.000 ton bahan cat antara 2007 dan 2011. Kisah serupa dapat ditemukan di Panasonic dengan produk whiteware-nya yang dapat mendeteksi dan mencatat perilaku penggunaan konsumen untuk memutuskan mode hemat energi. Produk-produk tersebut dirancang dan diproduksi oleh para mitranya dalam rantai pasokan. Selain itu, menerapkan teknologi secara bijak untuk menstandarkan dan memantau kegiatan rantai pasokan ramah lingkungan sangat penting untuk memastikan kinerja rantai pasokan ramah lingkungan. Ford menggunakan chip Radio Frequency Identification (RFID) untuk merekam gerakan logistik dari lini produksi dan persediaan seperti memfasilitasi efisiensi energi dan mengurangi transportasi yang tidak perlu. Tindakan ini berpotensi menciptakan dampak besar pada pengurangan emisi CO2 (Melville, 2010, seperti dikutip dari laporan Climate Group 2008).

Singkatnya, Rantai Pasokan Ramah lingkungan lebih dari sekadar strategi pasif tetapi dapat diimplementasikan sebagai strategi proaktif. Tidak hanya sebagaipengikut, perusahaan telah mulai memanfaatkan konsep dan kerangka terkait untuk memasarkan merek mereka serta menikmati keuntungan bekerja dengan mitra dagang di sumber, desain produk, manufaktur, dan pengiriman untuk membentuk pasokan ramah lingkungan rantai. Dalam hubungan ini, tujuan dari masalah khusus ini adalah untuk mencerminkan iklan terbaru tentang pemasaran industri ramah lingkungan, rantai pasokan ramah lingkungan/berkelanjutan dan interaksi mereka dalam branding industri ramah lingkungan, dan untuk mengeksplorasi arah penelitian di masa depan.

\section{Memindai Masalah}

Penelitian ini berisi juga tentang beberapa makalah berkualitas tinggi, yang masingmasing telah melalui setidaknya dua putaran tinjauan oleh setidaknya tiga pengulas makalah ini mencakup berbagai isu manajemen ramah lingkungan, seperti Manajemen Rantai Pasokan (MRP) dan kinerja ramah lingkungan, pengembangan dan inovasi produk ramah lingkungan, orientasi keberlanjutan, integrasi pemasaran ramah lingkungan dan MRP ramah lingkungan, perbandingan antara B2B (Bisnis 2 Bisnis) dan B2C (Bisnis 2 Customer) MRP ramah lingkungan, dan sebagainya. Makalah ini mencakup sektor publik dan sektor swasta; baik menggunakan penelitian pengujian hipotesis kuantitatif, penelitian induktif kualitatif, atau pengembangan kerangka kerja untuk praktik ramah lingkungan baru (yaitu pengembangan produk yang dibatasi sumber daya). Masalah khusus ini benar-benar internasional, karena 
data yang digunakan dalam makalah dalam masalah ini berasal dari berbagai negara, seperti Inggris, Cina, Prancis, Singapura, dan sebagainya.

Karya Cheng dan Sheu dalam masalah ini memberikan wawasan tentang bagaimana efek positif dari orientasi hubungan pada kualitas strategi antar-organisasi dapat dimoderasi oleh perilaku oportunistik dan konflik disfungsional dari kemitraan dalam rantai pasokan ramah lingkungan. Ini berbeda dengan penelitian sebelumnya yang lebih fokus pada anteseden terhadap kualitas strategi antar organisasi. Selain itu, studi mereka berkontribusi pada penelitian rantai pasokan ramah lingkungan dengan mengintegrasikan perspektif pandangan ekonomi dan relasional dalam studi tata kelola rasional dalam rantai pasokan ramah lingkungan, yang tidak dibahas dalam studi sebelumnya. Akhirnya, makalah ini memperluas penelitian saat ini dengan menyoroti peran hubungan berbasis nilai dari pandangan ekonomi dan relasional mitra.

Oruezabala dan Rico dalam masalah ini menyelidiki pengaruh orientasi berkelanjutan pada perjanjian dan kontrak pengadaan. Literatur pemasaran bisnis sebelumnya tidak membahas praktik pengadaan publik. Penelitian ini mengeksplorasi konsekuensi dari harapan yang lebih ramah lingkungan pada hubungan pembeli - penjual dari sudut pandang pembeli. Investigasi kualitatif mengungkapkan bahwa peraturan lingkungan baru menuntut aturan baru dalam norma formal dan relasional. Pengadaan berkelanjutan menyiratkan persyaratan lingkungan baru, pengurangan basis pemasok, kebutuhan akan inovasi berkelanjutan, legitimasi fungsi pembelian dan pendekatan biaya total kepemilikan. Akibatnya, tingkat dan sifat harapan dari penyedia berubah. Oruezabala dan Rico menegaskan bahwa pengadaan publik berkelanjutan cenderung berfokus pada lebih sedikit pemasok utama yang memliki keterampilan " ramah lingkungan" dan bahwa proses pengadaan kebutuhan untuk mengubah norma-norma implisit menjadi yang eksplisit dalam hal dampak lingkungan.

Pertanyaan penelitian utama Liu, Kasturiratne dan Moizer adalah bagaimana mengintegrasikan pemasaran ramah lingkungan dengan manajemen rantai pasokan yang berkelanjutan, sehingga kebutuhan pelanggan ramah lingkungan ini terpenuhi lebih baik dari kedua sisi permintaan dan penawaran. Makalah ini membahas model hub-and-spoke yang membahas integrasi dari berbagai dimensi, yaitu 6P (produk, promosi, perencanaan, proses, orang/people, dan proyek). Dibandingkan dengan integrasi B2B konvensional point-to-point, model integrasi 6P yang diusulkan memungkinkan lebih efektif informasi, bahan, orang dan aliran dana antara pemasaran dan kegiatan rantai pasokan. Model integrasi 6P telah dievaluasi melalui studi empiris dengan manajer industri. Kontribusi kunci dari makalah ini 
termasuk sejumlah implikasi manajerial yang telah menimbulkan melalui studi teori dan studi empiris dari model integrasi $6 \mathrm{P}$, serta pendorong utama dan hambatan yang telah diidentifikasi untuk integrasi multi-dimensi dari pemasaran ramah lingkungan dan berkelanjutan. Makalah ini memiliki relevansi tinggi dengan masalah khusus karena membahas salah satu tema utama yang didorong oleh masalah khusus, yaitu interaksi antara manajemen rantai ramah lingkungan/berkelanjutan dan pemasaran ramah lingkungan.

Sejalan dengan tujuan untuk mengeksplorasi praktik rantai pasokan ramah lingkungan saat ini di pasar industri, Lee dan Lam mengadopsi pendekatan studi kasus untuk mengeksplorasi bagaimana perusahaan mengatasi masalah terkait dengan layanan dan logistik aftermarket. Berdasarkan solusi dan ukuran yang diadopsi oleh perusahaan, kerangka kerja strategis termasuk analisis pasar ramah lingkungan, pengembangan pasar ramah lingkungan, manajemen operasi berkelanjutan dan akuisisi pelanggan telah diusulkan. 8 proposisi untuk keempat konstruksi penelitian dalam kerangka kerja yang diusulkan telah diturunkan dan didukung oleh tinjauan literatur terkait. Makalah ini memberikan manajer dan ahli logistik beberapa pedoman praktis dan wawasan ketika mereka mencoba untuk mengadopsi pendekatan yang lebih ramah lingkungan dalam bisnis mereka. Makalah ini telah menyoroti pentingnya analisis pasar ramah lingkungan dan pengembangan pasar ramah lingkungan sehingga dapat meningkatkan keunggulan kompetitif dan kinerja keuangan.

\section{KESIMPULAN}

Pengembangan produk yang dibatasi sumber daya adalah area yang kurang diteliti karena jenis inovasi ini terjadi di sejumlah besar negara dan konteks, tetapi jarang dilaporkan karena ukuran pasar yang kecil. Sebagian besar inovasi pengembangan produk yang terbatas sumber daya diproduksi dalam jumlah kecil untuk konteks yang sangat khusus Dalam lima tahun terakhir, pengembangan produk sumber daya terbatas telah menjadi bidang minat yang meningkat karena perusahaan besar telah mulai memanfaatkan proses ini. Oleh karena itu, fokus penelitian yang masih ada dalam pengembangan produk sumber daya terbatas tetap pada proses. Sharma dan Iyer menunjukkan bahwa ada tiga manfaat tambahan pengembangan produk sumber daya terbatas. Manfaat pertama adalah keunggulan kompetitif dipertahankan sebagai produk yang diproduksi dengan harga yang lebih rendah dengan fitur set yang diinginkan. Keuntungan kedua adalah produk sumber daya terbatas yang menggunakan lebih sedikit sumber daya, lebih berkelanjutan. Akhirnya, produk sumber daya terbatas dengan menggunakan komponen lebih sedikit dan tidak tersedia membuat rantai 
pasokan lebih ramah lingkungan dan efisien. Makalah ini sesuai dengan tema masalah khusus dengan memeriksa peran yang dimainkan pengembangan sumber daya produk terbatas dalam meningkatkan pemasaran ramah lingkungan dan efisiensi rantai pasokan.

Manajemen rantai pasokan ramah lingkungan (MRPRL) sering dikaitkan dengan organisasi yang sangat terlihat dan industri yang berfokus pada konsumen, dan karena itu MRPRL dalam konteks rantai pasokan industri sering diabaikan. Hoejmose dkk memberikan salah satu analisis paling komprehensif tentang manajemen rantai pasokan "ramah lingkungan" di UK dan mereka secara eksplisit menghubungkan dan membandingkan MRPRL di perusahaan-perusahaan di sektor B2B dan B2C. Oleh karena itu, mereka berusaha untuk memahami tingkat MRPRL di sektor B2B dan B2C, dan yang lebih penting kondisi di mana MRPRL akan mendorong dalam pengaturan B2B. Untuk tujuan ini, mereka menggunakan pendekatan pengumpulan data baru untuk menangkap MRPRL, yang meminimalkan keinginan sosial dan bias sumber umum. Studi ini memperluas pemahaman tentang sejauh mana MRPRL bergantung pada teks. Selain itu, mereka memeriksa kondisi di mana MRPRL kemungkinan berhasil diterapkan. Lebih khusus, Artikel ini mempertimbangkan bagaimana kepercayaan dan dukungan manajemen puncak berperan dalam membentuk MRPRL di rantai pasokan B2B dan B2C. Hasil menunjukkan bahwa MRPRL relatif terbatas di antara perusahaan di pasar B2B dibandingkan dengan perusahaan di pasar B2C. Pada saat yang sama, Hoejmose dkk menunjukkan bahwa mengembangkan kepercayaan dengan mitra rantai pasokan, sementara juga memiliki dukungan manajemen puncak, merupakan pendorong penting dari keterlibatan dengan MRPRL di antara perusahaan di sektor B2B tetapi kurang penting di antara perusahaan di sektor B2C. Temuan ini memberikan wawasan yang cukup besar bagi para manajer dan pemasar rantai pasokan B2B yang berupaya merespons minat yang meningkat terhadap kinerja lingkungan dari rantai pasokan.

Penelitian Chan, He, Chan dan Wang secara empiris menguji hubungan antara orientasi lingkungan, kegiatan MRPRL dan kinerja perusahaan, serta bagaimana faktor konteks yang penting, intensitas persaingan dapat memoderasi (memperkuat) hubungan ini lebih jauh. Dalam pandangan perusahaan meningkatnya penggunaan praktek MRPRL untuk menjawab tuntutan lingkungan dari berbagai pemangku kepentingan yang menonjol dan potensi untuk mempekerjakan MRPRL untuk meningkatkan operasi pemasaran seperti produk dan desain kemasan, komunikasi dan pilihan saluran pemasaran, penelitian ini dianggap tepat waktu dan penting untuk memperkaya literasi pemasaran yang ada, yang 
secara tradisional hanya memberi perhatian terbatas pada implikasi strategis MRPRL. Dengan mensurvei perusahaan investasi asing yang beroperasi di Cina, penelitian ini menunjukkan bahwa perusahaan yang berorientasi lingkungan lebih mungkin untuk berlatih kegiatan MRPRL. Kegiatan ini mencakup penggunaan strategis perusahaan tentang daur ulang, pemindahan dan menjual kembali untuk meningkatkan nilai material dan produknya, dan bekerjasama dengan pemasok dan pelanggan untuk masing-masing meramah lingkungankan kegiatan logistiknya yang masuk dan keluar. Dengan lebih lanjut menunjukkan bahwa kegiatan MRPRL ini secara positif mempengaruhi kinerja perusahaan, studi ini, antara lain, mengingatkan pemasar industri tentang pentingnya memperkuat kerja sama dengan pelanggan mereka untuk mencapai pangsa pasar yang lebih tinggi dan pertumbuhan pasar di pasar yang sangat kompetitif saat ini.

\section{DAFTAR PUSTAKA}

Ambec, S., \& Lanoie, P. (2008). Does It Pay to Be Green? A Systematic Overview. Academy of Management Perspectives, 22(4), 45-62.

Australian Competition and Consumer Commission (2011). Green marketing and the Australian Consumer Law. Accessed on 13/12/2019: http://www.accc.gov.au/content/ index.phtml/itemId/815763

Bai, C., \& Sarkis, J. (2010). Green supplier development: analytical evaluation using rough set theory. Journal of Cleaner Production, 18(12), 1200-1210.

Baker, W. E., \& Sinkula, J. M. (2005). Environmental Marketing Strategy and Firm Performance: Effects on New Product Performance and Market Share. Journal of the Academy of Marketing Science, 33(4), 461-475.

Banerjee, S. B., Iyer, E. S., \& Kashyap, R. K. (2003). Corporate Environmentalism: Antecedents and Influence of Industry Type. Journal of Marketing, 67(2), 106-122.

Blackburn, J. D., Guide, V. D. R., Souza, G. C., \& Van Wassenhove, L. N. (2004). Reverse Supply Chains for Commercial Returns. California Management Review, 46(2), 6-22.

Bowen, F. E., Cousins, P. D., Lamming, R. C., \& Faruk, A. C. (2001). The role of supply management capabilities in green supply. Production and Operation Management, 10(2), 174-189.

Bruce, M., Daly, L., \& Towers, N. (2004). Lean or agile: a solution for supply chain management in the textiles and clothing industry?. International Journal of Operations and Pro-duction Management, 24(2), 151-170.

Chan, H. K. (2007). A proactive and collaborative approach to reverse logistics: a case study. Production Planning \& Control, 18(4), 350-360. 
Chan, R. Y. K. (2010). Corporate Environmentalism Pursuit by Foreign Firms Competing in China. Journal of World Business, 45(1), 80-92.

Chan, H. K. (2011). Supply Chain Systems - Recent Trend in Research and Applications. IEEE Systems Journal, 5(1), 2-5.

Chan, H. K., \& Chan, F. T. S. (2010). Comparative Study of Adaptability and Flexibility in Distributed Manufacturing Supply Chains. Decision Support Systems, 48(2), 331-341.

Chan, R. Y. K., He, H., Chan, H. K., Wang, W. Y. C. (this issue). Environmental Orientation and Corporate Performance: The Mediation Mechanism of Green Supply Chain Management and Moderating Effect of Competitive Intensity. Industrial Marketing Management.

Chan, H. K., Yin, S., \& Chan, F. T. S. (2010). Implementing just-in-time philosophy to reverse logistics systems: a review. International Journal of Production Research, 48(21), 6293-6313.

Chen, Y. S., Lai, S. B., \& Wen, C. T. (2006). The influence of green innovation performance on corporate advantage in Taiwan. Journal of Business Ethics, 67(4), 331-339.

Cheng, J. H., Sheu, J. B. (this issue). Inter-organizational relationships and strategy quality in green supply chains: moderating by opportunistic behavior and dys-functional conflict. Industrial Marketing Management.

Chiou, T. -Y., Chan, H. K., Lettice, F., \& Chung, S. H. (2011). Influence of Greening the Suppliers and Green Innovation on Environmental Performance and Competitive Advantage. Transportation Research Part E: Logistics and Transportation Review, 47(6), 822-836.

Côté, R. P., Lopez, J., Marche, S., Perron, G. M., \& Wright, R. (2008). Influences, practices and opportunities for environmental supply chain management in Nova Scotia SMEs. Journal of Cleaner Production, 16(15), 1561-1570.

Cronin, J. J., Smith, J. S., Gleim, M. R., Ramirez, E., \& Martinez, J. D. (2011). Green marketing strategies: an examination of stakeholders and the opportunities they present. Journal of the Academy of Marketing Science, 39(1), 158-174.

Edwards, J. B., McKinnon, A. C., \& Cullinane, S. L. (2010). Comparative analysis of the carbon footprints of conventional and online retailing: A "last mile" perspective. International Journal of Physical Distribution and Logistics Management, 40(1/2), $103-123$.

Egri, C. P., \& Herman, S. (2000). Leadership in the North American environmental sector: Values, leadership styles, and contexts of environmental leaders and their organizations. Academy of Management Journal, 43(4), 571-604.

Federal Trade Commission of the United State (2012). Guides for the Use of Environmental Marketing Claims. Accessed on 13/12/2019: http://www.ftc.gov/bcp/grnrule/guides980427.htm 
Godfrey, R. (1998). Ethical purchasing: developing the supply chain beyond the environment. In T. Russel (Ed.), Greener Purchasing: Opportunities and Innovations (pp. 244-251). Sheffield, England: Greenleaf Publishing.

Green, K., Morton, B., \& New, S. (1996). Purchasing and environmental management: interaction, policies and opportunities. Business Strategy and the Environment, 5, 188197.

Green, K., Morton, B., \& New, S. (1998). Green purchasing and supply policies: do they improve companies' environmental performance?. Supply Chain Management: An International Journal, 3(2), 89-95.

Handelman, J. M., \& Arnold, S. J. (1999). The role of marketing actions with a social dimension: Appeals to the institutional environment. Journal of Marketing, 63(July), $33-48$.

Hervani, A. A., Helms, M. M., \& Sarkis, J. (2005). Performance measurement for green supply chain management. Benchmarking: An International Journal, 12(4), 330-353.

Hines, P., Holweg, M., \& Rich, N. (2004). Learning to evolve - a review of contemporary lean thinking. International Journal of Operations \& Production Management, 24(10), 914-1011.

Hoejmose, S., Brammer, S., \& Millington, A. (this issue). "Green” supply chain management: The role of trust and topmanagement in B2B and B2C supply relationships. Industrial Marketing Management.

International Organization for Standardization, ISO 14001:2004 (2004). Accessed on 5/12/2019. http://www.iso.org/iso/catalogue_detail?csnumber=31807

Jüttner, U., Christopher, M., \& Baker, S. (2007). Demand chain management-integrating marketing and supply chain management. Industrial Marketing Management, 36(3), 377-392.

Kroon, L. And, \& Vrijens, G. (1995). Returnable containers: and example of reverse logistics. International Journal of Physical Distribution \& Logistics, 25(2), 56-68.

Lambert, D. M., \& Cooper, M. C. (2000). Issues in Supply Chain Management. Industrial Marketing Management, 29(1), 65-83.

Lamming, R., \& Hampson, J. (1996). The Environment as a Supply Chain Management Issue. British Journal of Management, 7, S45-S62.

Lau, A. K. W., Tang, E., \& Yam, R. C. M. (2010). Effects of supplier and customer integration on product innovation and performance: Empirical evidence in Hong Kong manufacturers. Journal of Product Innovation Management, 27(5), 761-777.

Lee, C. K. M., Lam, J. S. L. (this issue). Managing reverse logistics to enhance sustainability of industrial marketing. Industrial Marketing Management.

Liu, S., Kasturiratne, D., Moizer, J. (this issue). A hub-and-spoke model for multidimensional integration of green marketing and sustainable supply chain management. Industrial Marketing Management. 
Maxwell, D., \& Van der Vorst, R. (2003). Developing sustainable products and services. Journal of Cleaner Production, 11(8), 883-895.

Melville, N. P. (2010). Information Systems Innovation for Environmental Sustainability. MIS Quarterly, 34(1), 1-21.

Menguc, B., \& Ozanne, L. K. (2005). Challenges of the "green imperative": a natural resource-based approach to the environmental orientation-business performance relationship. Journal of Business Research, 58(4), 430-438.

Menon, A., \& Menon, A. (1997). Enviropreneurial Marketing Strategy: The Emer-gence of Corporate Environmentalism as Market Strategy. Journal of Marketing, 61(1), 51-67.

Messelbeck, J., \& Whaley, M. (1999). Greening the health care supply chain: triggers of change, models for success. Corporate Environmental Strategy, 6(1), 39-45.

Mustaffa, N. H., \& Potter, A. (2009). Healthcare supply chain management in Malaysia: a case study. Supply Chain Management: An International Journal, 14(3), 234-243.

Narasimhan, R., \& Carter, J. R. (1998). Linking business unit and material sourcing strategies. Journal of Business Logistics, 19(2), 155-171.

Oruezabala, G., Rico, J.-C. (this issue). The impact of sustainable public procurement on supplier management: The case of French public hospitals. Industrial Marketing Management.

Ragatz, G. L., Handfield, R. B., \& Petersen, K. J. (2002). Benefits associated with supplier integration in new product development under conditions of technology uncertainty. Journal of Business Research, 55(5), 389-400.

Rao, P., \& Holt, D. (2005). Do green supply chains lead to competitiveness and economic performance?. International Journal of Operation \& Production Management, 25(9), 898-916.

Russo, M. V., \& Fouts, P. A. (1997). A Resource-Based Perspective on Corporate Environmental Performance and Profitability. The Academy of Management Journal, 40(3), 534-559.

Sarkis, J., Gonzalez-Torre, P., \& Adenso-Diaz, B. (2010). Stakeholder pressure and the adoption of environmental practices: The mediating effect of training. Journal of Operations Management, 28(2), 163-176.

Schmidt, M., \& Schwegler, R. (2008). A recursive ecological indicator system for the supply chain of a company. Journal of Cleaner Production, 16(15), 1658-1664.

Sharma, A., Iyer, G. R. (this issue). Resource-constrained product development: Implications for green marketing and green supply chains. Industrial Marketing Management.

Siegel, D. (2009). Green Management Matters Only If It Yields More Green: An Economic/Strategic Perspective. The Academy of Management Perspectives, 23(3), 516. 
Vachon, S., \& Klassen, R. D. (2008). Environmental management and manufacturing performance: The role of collaboration in the supply chain. International Journal of Production Economics, 111(2), 299-315.

Yung, W. K. C., Chan, H. K., So, J. H. T., Wong, D. W. C., Choi, A. C. K., \& Yue, T. M. (2011). A life-cycle assessment for eco-redesign of a consumer electronic product: a case study. Journal of Engineering Design, 22(2), 69-85.

Zhu, Q., \& Sarkis, J. (2004). Relationships between operational practices and performance among early adopters of green supply chain management practices in Chinese manufacturing enterprises. Journal of Operations Management, 22(3), 265-289. 